\title{
Role of Body-Fluid Biomarkers in Alzheimer's Disease Diagnosis
}

\author{
Thuy Trang Nguyen ${ }^{1, \dagger}$, Qui Thanh Hoai Ta ${ }^{2, \dagger}$, Thi Kim Oanh Nguyen ${ }^{3}$, \\ Thi Thuy Dung Nguyen ${ }^{4, *}$ and Van Giau Vo $5,6, *$ (D) \\ 1 Faculty of Pharmacy, Ho Chi Minh City University of Technology (HUTECH), \\ Ho Chi Minh City 700000, Vietnam; nt.trang85@hutech.edu.vn \\ 2 Institute of Research and Development, Duy Tan University, Danang 550000, Vietnam; \\ tathoaiqui@duytan.edu.vn \\ 3 Faculty of Food Science and Technology, Ho Chi Minh City University of Food Industry, \\ Ho Chi Minh City 700000, Vietnam; oanhntk@hufi.edu.vn \\ 4 Faculty of Environmental and Food Engineering, Nguyen Tat Thanh University, \\ Ho Chi Minh City 70000, Vietnam \\ 5 Department of Industrial and Environmental Engineering, Graduate School of Environment, \\ Gachon University, 1342 Sungnam-daero, Sujung-gu, Seongnam-si, Gyeonggi-do 461-701, Korea \\ 6 Department of BionanoTechnology, Gachon University, 1342 Sungnam-daero, Sujung-gu, \\ Seongnam-si, Gyeonggi-do 461-701, Korea \\ * Correspondence: dungntt@ntt.edu.vn (T.T.D.N.); giauvvo@gmail.com (V.G.V.) \\ + These authors contributed equally to this work.
}

Received: 7 April 2020; Accepted: 19 May 2020; Published: 20 May 2020

\begin{abstract}
Alzheimer's disease (AD) is a complex neurodegenerative disease that requires extremely specific biomarkers for its diagnosis. For current diagnostics capable of identifying $\mathrm{AD}$, the development and validation of early stage biomarkers is a top research priority. Body-fluid biomarkers might closely reflect synaptic dysfunction in the brain and, thereby, could contribute to improving diagnostic accuracy and monitoring disease progression, and serve as markers for assessing the response to disease-modifying therapies at early onset. Here, we highlight current advances in the research on the capabilities of body-fluid biomarkers and their role in AD pathology. Then, we describe and discuss current applications of the potential biomarkers in clinical diagnostics in AD.
\end{abstract}

Keywords: Alzheimer's disease; biomarkers; diagnostics; A $\beta$; CSF; tau

\section{Introduction}

Alzheimer's disease is an irreversible, progressive brain disorder, characterized by the accumulation of $\beta$-amyloid $(\mathrm{A} \beta)$ plaques and tangles consisting of hyperphosphorylated tau protein in the brain. It accounts for $60-70 \%$ of dementia cases, making it the most common cause of dementia [1,2]. Globally, it is predicted to go up to over 131 million by 2050 [3] due to the increasing of the number of elderly. Approximately $>5 \%$ of all patients with AD are diagnosed before age 65 and are grouped as early onset AD (EOAD) [4,5], while patients with AD after age 65 are grouped as late onset AD (LOAD) [4,5]. For the diagnosis of AD, these morphological abnormalities in brain cells and tissues are used for clinical evaluations. Clinical AD is mainly characterized by two key factors including intracellular neurofibrillary tangles (NFT) and extracellular amyloid plaques or senile plaques [6], with the hyperphosphorylation of tau oligomer protein [7]. In addition, amyloid plaques are suggested to be critical features of AD neuropathology [8]. With a 40-42 bp length, A $\beta$ peptides are suggested to be the main components of these plaques [9], which result in abnormal folding of the $A \beta$ peptides 
due to oligomers or fibrils in the brain tissue. In addition, in rare cases, the disease is inherited in an autosomal dominant early onset form caused by mutations in the amyloid precursor protein $(A P P)$, presenilin 1 (PSEN1), and presenilin 2 (PSEN2) genes, which might result in the alteration of $\mathrm{A} \beta$ production, leading to the apoptosis of the neurons and dementia $[4,5]$.

Although there is no effective treatment capable of slowing down disease progression, it is believed to have a long preclinical phase, during which the affected individual has no or very subtle decline in cognition but manifests AD biomarker positivity. The characterization of the preclinical stage of $\mathrm{AD}$ first became possible following neuroimaging with magnetic resonance imaging (MRI) and positron emission tomography (PET), reflecting cerebral amyloidosis, tau phosphorylation and neurodegeneration. The time span of preclinical AD has, as yet, not been fully elucidated, as it seems to manifest some individual variability and could be affected by factors such as cognitive reserve, genetic profile and lifestyle. However, mounting evidence suggests that the preclinical stage is generally long, stretching over years or even decades. To alter the disease state, the drugs need to be directed towards the specific targets, and without the molecular understanding of the mechanisms and biomarkers, that is not possible [10]. Since there is no specific signature biomarker, the diagnosis of AD used to combine a multi-step process of confirming a wide range of biomarkers. The most targeted fluid biomarkers could be considered to be constituted of cerebrospinal fluid (CSF) biomarkers. However, collecting the CSF samples and confirming the biomarkers is time consuming and expensive. Thus, there should be alternative biomarkers to be used in a large number of populations. Thus, blood-based biomarkers would be the first step of the multiple steps. These biomarkers can be applied to predict the disease, and then the CSF biomarkers can contribute towards confirming the disease as early as possible [11,12]. Hence, the biomarkers become the most important factors in the early diagnosis of the disease. The purpose of this review was to provide an overview of recent body-fluid biomarkers and their role in AD pathology. Additionally, we describe current applications of the biomarkers in the development of approaches for the early diagnosis of AD.

\section{Biomarkers in Alzheimer's Disease}

Biomarkers that can be used in vivo are essential in mapping the chain of events in AD, from the preclinical stage to the clinical stage. The characterization of preclinical AD would not be possible without the use of biomarkers, as no clinical symptoms have yet emerged. Biomarkers are also useful in selecting patients for clinical trials and for monitoring treatment effects. In the NIA-AA guidelines for AD diagnosis, the clinical use of biomarkers is optional, but it has still become widespread in the clinical setting, mainly as a supportive rather than decisive tool. This includes the CSF biomarkers A $\beta 42$, total tau-protein (t-tau) and phosphorylated tau protein ( $\mathrm{p}$-tau), as well as FDG-PET, amyloid PET and structural MRI. These biomarkers reflect two of the hallmarks of AD, cerebral amyloidosis (CSF A 342 and amyloid PET) and neurodegeneration (CSF t-tau and p-tau, FDG-PET and structural MRI). Experimental biomarkers reflecting other pathological processes are under development, both as possible diagnostic aids and for the further characterization of the natural history of AD. These include novel CSF biomarkers and PET ligands as well as blood based biomarkers [11] and electroencephalographic algorithms [13,14]. When these $A \beta$ plaques aggregate and cannot get metabolized they induce another cascade of inflammation [15]. In addition, urine and ocular inflammatory biomarkers in the retina of the eye may be additional biomarkers for early $\mathrm{AD}$ detection. Combining all the biomarkers of $\mathrm{AD}$, they can be divided into a few classes like CSF biomarkers, imaging biomarkers, blood biomarkers, ocular biomarkers and urine biomarkers.

The most promising biomarkers of AD are cerebrospinal fluid $\mathrm{A} \beta$ peptides in conjunction with CSF tau-proteins. In AD patients, the amount of CSF A $\beta$ protein decreases gradually with increased $\tau$-proteins. APP has a major role in depositing amyloid plaques, and here, amyloid proteins are the metabolic products of the neurons, which are produced through cascades of cleavage reactions where the major role players are the $\alpha, \beta$ and $\gamma$ secretases [16]. As previously mentioned, both A $\beta$ and phosphorylated tau could be the main components of extracellular plaques and neurofibrillary 
tangles that may constitute the core biomarkers for AD detection [17]. In AD patients, the abnormal of t-tau/p-tau in the CSF may result in increased tau secretion and phosphorylation $[17,18]$. While the difference between topographic biomarkers (PET-FDG; MRI) and pathophysiological biomarkers (CSF, amyloid PET) have been well established [19], CSF biomarkers could be a specific physiopathological process of the disease. The presence of amyloid beta oligomer $(\mathrm{A} \beta \mathrm{O})$ has been correlated with synaptic plasticity impairment and frank synapse loss in mice and cell models [20-23] and in human brains in $\mathrm{AD}[24,25]$. The cognitive impairment in AD closely parallels the loss of synapses due to the toxic effects of $A \beta$, tau, and inflammation; thus, emerging biomarkers are able to measure synapse injury and loss in the brain and may correlate with cognitive function in $\mathrm{AD}$ [26].

\section{Biomarkers in the Cerebrospinal Fluid}

\subsection{Cerebrospinal Fluid $A \beta$}

CSF A $\beta 42$ may remain the quintessential fluid AD biomarkers for now, but a growing cadre of other markers are also proving their worth [27]. Three core CSF biomarkers, $A \beta 42$, $p$-tau and $t$-tau, have been extensively evaluated for use in AD diagnosis and research. Clinically, studies have revealed that the level of $A \beta 42$ is lower, while the figures of t-tau and p-tau are usually higher in AD patients in comparison to in healthy elderly people [28]. In addition, previous studies have reported that CSF $\mathrm{A} \beta 42$ decreases early in the pathological cascade of $\mathrm{AD}$ and remains stable and low thereafter [29-32], making it an unsuitable marker of disease severity and the rate of progression. CSF A $\beta 42$ has been observed to already be reduced in prodromal $\mathrm{AD}$ and even in the preclinical asymptomatic stage of AD [33-38]. Recently, studies of biomarker classification proposed a new research framework in an effort to nudge the field toward a biological definition of AD. In 2014, the International Working Group 2 (IWG-2) for New Research Criteria for the Diagnosis of AD suggested a new conceptual framework for the presence of biomarker evidence consistent with and supportive of AD [39]. This study enabled $\mathrm{AD}$ diagnosis to be extended into the prodromal stage, where the disease can be diagnosed with supportive biomarkers. It adding the value of the combinations of CSF markers including $t$-tau, A $\beta 1-42$ and p-tau [40] that been confirmed in large multi-center studies-namely, the Alzheimer's Disease Neuroimaging Initiative (ADNI) study [41] and the Development of Screening Guidelines and Criteria for Predementia Alzheimer's Disease (DESCRIPA) study [42]. The framework defined AD as the presence of plaque and tangle pathology, regardless of symptoms, and offered a systematic definition of pathological changes based on biomarkers for brain amyloid, tau and neurodegeneration. They classified them according to the $\mathrm{A} / \mathrm{T} / \mathrm{N}$ scheme into those of $\beta$-amyloid deposition, using CSF $\mathrm{A} \beta 1-42$ for brain amyloid (A), CSF p-tau181 for aggregated tau (T), and FDG-PET for neurodegeneration (N). Each participant's values were deemed normal or abnormal based on the cutoffs determined in the ADNI. The binary classification of each of these three biomarker types bins people into eight possible profiles, ranging from completely negative $(A-/ T-/ N-)$ to triply positive $(A+/ T+/ N+)[10,43]$. In other words, a person's biomarker evaluation should include amyloid and tau status, and markers for neurodegeneration. How the " $\mathrm{N}$ " is measured will depend on local circumstances, and it is used to predict and monitor the course of the disease [44]. AD and other dementias could be distinguished based on the CSF $A \beta 42 / A \beta 40$ ratio, which may improve the detection of amyloid deposition into the CSF $[45,46]$. However, despite A $\beta$ maintaining its centrality in AD pathogenesis, it is not sufficient as predictor for $\mathrm{AD}$ [47]. Combination with other biomarkers such as $\mathrm{t}$-tau and $\mathrm{p}$-tau could be useful to diagnose $\mathrm{AD}$ cognitive decline as well as to differentiate $\mathrm{AD}$ from other forms of dementia more precisely. Figure 1 summarizes the evolution of the core cerebrospinal fluid AD biomarkers to date. 


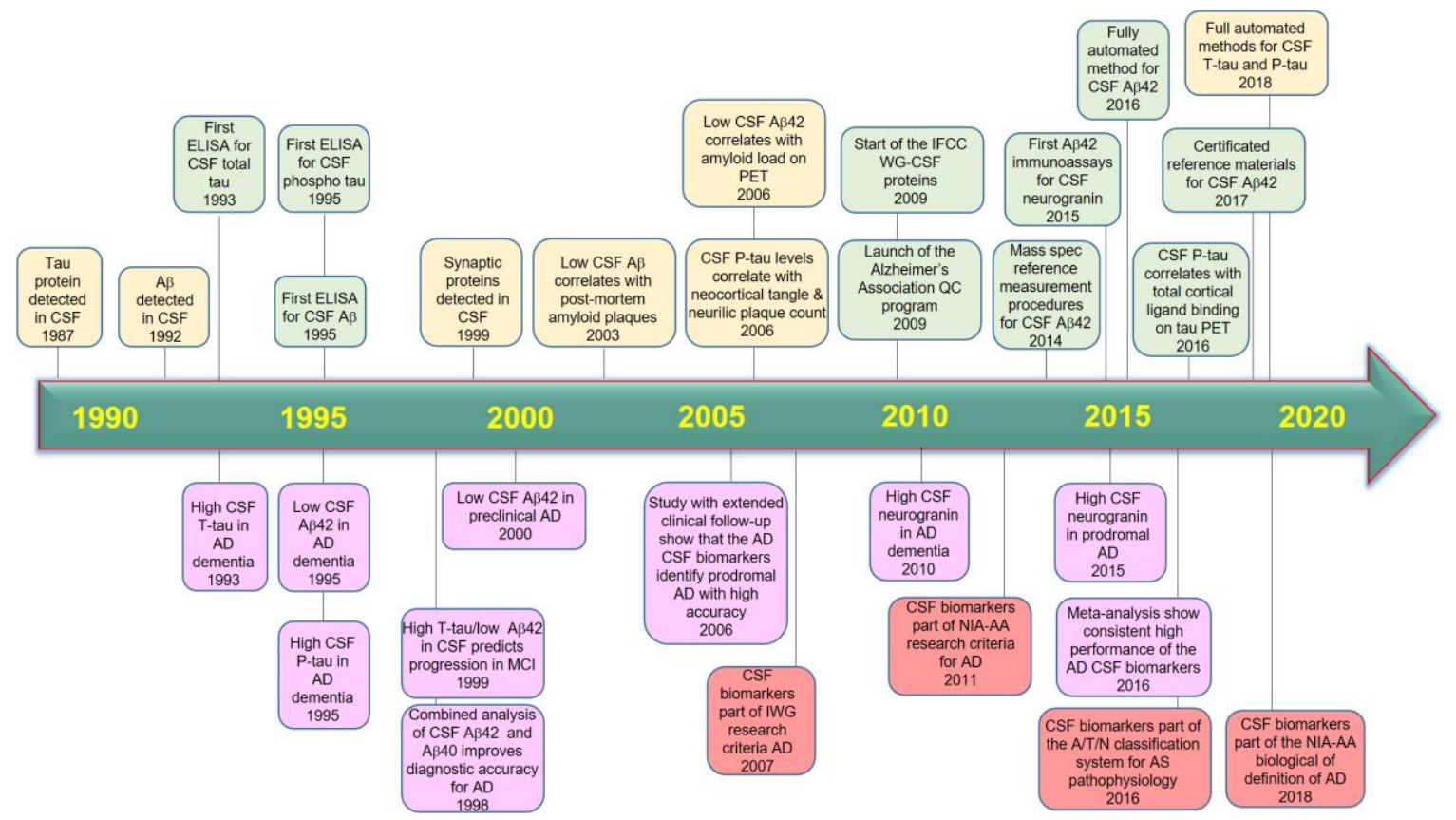

Figure 1. A timeline reflecting the evolution of the body fluid Alzheimer's disease biomarkers. Green boxes, technical developments; yellow boxes, pathophysiological findings; purple boxes, clinical findings; brown boxes, evolution of clinical diagnostic criteria and pathogenic classifications. $\mathrm{A} \beta$, amyloid beta; AD, Alzheimer's disease; CSF, cerebrospinal fluid; MCI, mild cognitive impairment; $\mathrm{N}$, neurodegeneration.

\subsection{Cerebrospinal Fluid P-Tau}

P-tau is the hyperphosphorylated form of the microtubule associated protein tau. The second AD CSF biomarker is p-tau, which reflects tau phosphorylation and increases by around $200 \%$ from control levels in $\mathrm{AD}$, most likely before the onset of the prodromal stage, and remains steady and high thereafter [48,49]. Assays are available both for p-tau181 and at threonine 231 (p-tau231). These are considered to be equivalent in diagnostic accuracy [50], although there is a possibility that p-tau231 has a somewhat greater specificity for AD than p-tau181 [51]. The increase in CSF p-tau has, as of yet, not been observed with certainty in other pathological conditions, making elevated p-tau seemingly exclusive to $\mathrm{AD}$. Interestingly, the measurement of the CSF tau/A $\beta 42$ [52] or $\mathrm{p}$-tau/A $\beta 42$ [53] ratios could raise diagnostic accuracy and may, therefore, be suitable for routine clinical use.

\subsection{Cerebrospinal Fluid T-Tau}

The next core CSF biomarker is t-tau, which represents axonal degeneration and increases by around $300 \%$ early in the course $\mathrm{AD}$, probably around the same time as p-tau [54,55]. T-tau is the least specific for $\mathrm{AD}$ of the three core CSF biomarkers, with increases in t-tau being observed in other neurological conditions [56]. Combining all three core CSF biomarkers yields a higher sensitivity and specificity for $\mathrm{AD}$ than can be achieved using only one or two of them. The combination of the reduced concentration of $\mathrm{A} \beta 42$ and high concentrations of $\mathrm{p}$-tau and $\mathrm{t}$-tau comprises the so called " $\mathrm{AD}$ signature" in CSF, which has been shown to be highly predictive of progression to AD dementia in mild cognitive impairment (MCI) patients [41,54,57-59]. An example of this is a study showing a $95 \%$ sensitivity and $87 \%$ specificity of the "AD signature" in the CSF in distinguishing between prodromal $\mathrm{AD}$ and stable MCI [59]. Some CSF candidate biomarkers for AD diagnosis are summarized in Table 1. 
Table 1. The presence of $A \beta 42$, p-tau and t-tau in CSF corresponds with pathology as core biomarkers (Notes: $\uparrow$, increased; $\downarrow$, decreased).

\begin{tabular}{|c|c|c|c|c|c|}
\hline Sample Size & Biomarker(s) & Cut-Off & Sensitivity & Specificity & Reference \\
\hline \multirow{2}{*}{$21 \mathrm{AD}$} & $\downarrow \mathrm{A} \beta 42$ & $\mathrm{~A} \beta 42:<427 \mathrm{ng} / \mathrm{L}$ & $86 \%$ & $88 \%$ & \multirow{3}{*}[60]{} \\
\hline & $\uparrow \mathrm{t}$-tau & t-tau: $<445 \mathrm{ng} / \mathrm{L}$ & $86 \%$ & $88 \%$ & \\
\hline 24 normals & $\uparrow \mathrm{p}$-tau & p-tau: $<74$ ng/L & $60 \%$ & $88 \%$ & \\
\hline $180 \mathrm{MCI}$ & $\downarrow \mathrm{A} \beta 42 \downarrow$ p-tau181 & t-tau: > $50 \mathrm{ng} / \mathrm{L}$ & \multirow{2}{*}{$95 \%$} & \multirow{2}{*}{$83 \%$} & \multirow{2}{*}{ [59] } \\
\hline 57 MCI-AD & $\uparrow \mathrm{t}$-tau & p-tau181: > $60 \mathrm{ng} / \mathrm{L}$ & & & \\
\hline \multirow{2}{*}{$137 \mathrm{MCI}$} & $\downarrow \mathrm{A} \beta 42$ & $\mathrm{~A} \beta 42: \leq 0.64 \mathrm{ng} / \mathrm{mL}$ & $93 \%$ & $53 \%$ & \multirow{2}{*}{ [59] } \\
\hline & $\downarrow \mathrm{A} \beta 42 / \mathrm{A} \beta 40$ ratio & $\mathrm{A} \beta 42-\mathrm{A} \beta 40: \leq 0.95$ & $87 \%$ & $78 \%$ & \\
\hline 529 AD & $\downarrow \mathrm{A} \beta 42$ & $\mathrm{~A} \beta 42: \leq 482 \mathrm{ng} / \mathrm{l}$ & $79 \%$ & $65 \%$ & \multirow{3}{*}[61]{} \\
\hline 304 normal & $\uparrow \mathrm{t}$-tau & t-tau: $\geq 320 \mathrm{ng} / \mathrm{l}$ & $84 \%$ & $47 \%$ & \\
\hline $271 \mathrm{AD}$ & $\uparrow \mathrm{p}$-tau & p-tau: $\geq 52 \mathrm{ng} / \mathrm{l}$ & $86 \%$ & $56 \%$ & \\
\hline $24 \mathrm{AD}$ & $\mathrm{A} \beta 42$ & t-tau: $>325.7 \mathrm{pg} / \mathrm{mL}$ & $83 \%$ & $91 \%$ & [62] \\
\hline $76 \mathrm{AD}$ & $\uparrow \mathrm{t}$-tau & $\mathrm{A} \beta 42:<481 \mathrm{pg} / \mathrm{mL}$ & $94 \%$ & $87 \%$ & \multirow{6}{*}{ [63] } \\
\hline \multirow{5}{*}{47 dementia } & \multirow{5}{*}{$\uparrow \mathrm{p}$-tau } & t-tau: > $326 \mathrm{pg} / \mathrm{mL}$ & $84 \%$ & $96 \%$ & \\
\hline & & p-tau: > 57 pg/mL & $72 \%$ & $90 \%$ & \\
\hline & & t-tau/A $\beta 42:>0.55$ & $99 \%$ & $95 \%$ & \\
\hline & & $\mathrm{p}-\mathrm{tau} / \mathrm{A} \beta 42:>0.10$ & $96 \%$ & $96 \%$ & \\
\hline & & $\mathrm{t}-\mathrm{tau} / \mathrm{A} \beta 42:>0.081$ & $93 \%$ & $70 \%$ & \\
\hline
\end{tabular}

\section{Biomarkers in Blood}

\subsection{Plasma $A \beta$}

CSF biomarkers have dominated the biomarkers, with low levels of CSF A $\beta 42$ showing a reliable correlation with AD risk [64]. Amyloid in the blood, on the other hand, has yielded a more confusing picture. Some studies have found a relationship between low levels of plasma $A \beta$ and the development of Alzheimer's [65-70], including one from last year that followed more than 1000 elderly people in France over four years [71]. Other work, meanwhile, has shown the opposite pattern, with high levels of plasma $A \beta$ correlating with disease risk [69,72-74]. One possible explanation that has been put forth for this discrepancy is that plasma $A \beta$ might be high initially in people at risk for AD [69,72]. Several studies have failed to find any strong association between plasma $A \beta$ and cognition [68-70,72-74].

Currently, AD is typically detected and diagnosed through memory and cognitive tests or MRI and PET scans of the brain, which can show evidence of tau or amyloid buildup. As mentioned above, although CSF biomarkers provide a more accurate diagnosis of $\mathrm{AD}$, blood biomarkers have advantages over the CSF biomarkers $[15,18]$. In addition, blood samples can be very easily collected from the patients, while the collection of the CSF samples needs procedures that require lumber punctures. Therefore, it becomes a great drawback of the CSF biomarkers in comparison to the blood biomarkers $[75,76]$ due to its stability. However, assaying $A \beta$ proteins in the blood becomes difficult when other proteins present in the blood interfere with the procedure, or the sample can even undergo photolytic reactions [18]. Figure 2 summarizes AD biomarkers in the blood.

A range of blood-based $A \beta$ assays have been recently developed based on immunoassays, promising for early AD detection [77]. To distinguish $A D$ samples and controls through the $A \beta 42 / A \beta 40$ ratio, several assays have been developed and applied to detect $A \beta 40$ in the plasma such as a single molecule array (Simoa) [78,79], immunomagnetic reduction (IMR) [80,81] or enzyme-linked sandwich immunoassay (ELISA) [82]. An additional plasma A $\beta$ test, an immunoprecipitation method, 
was developed and able to measure abnormal total $A \beta$ in the plasma [83]. Using those techniques could measure $\mathrm{A} \beta$ aggregates or $\mathrm{A} \beta$ bound to other proteins at the low amounts in the AD plasma [80,84].

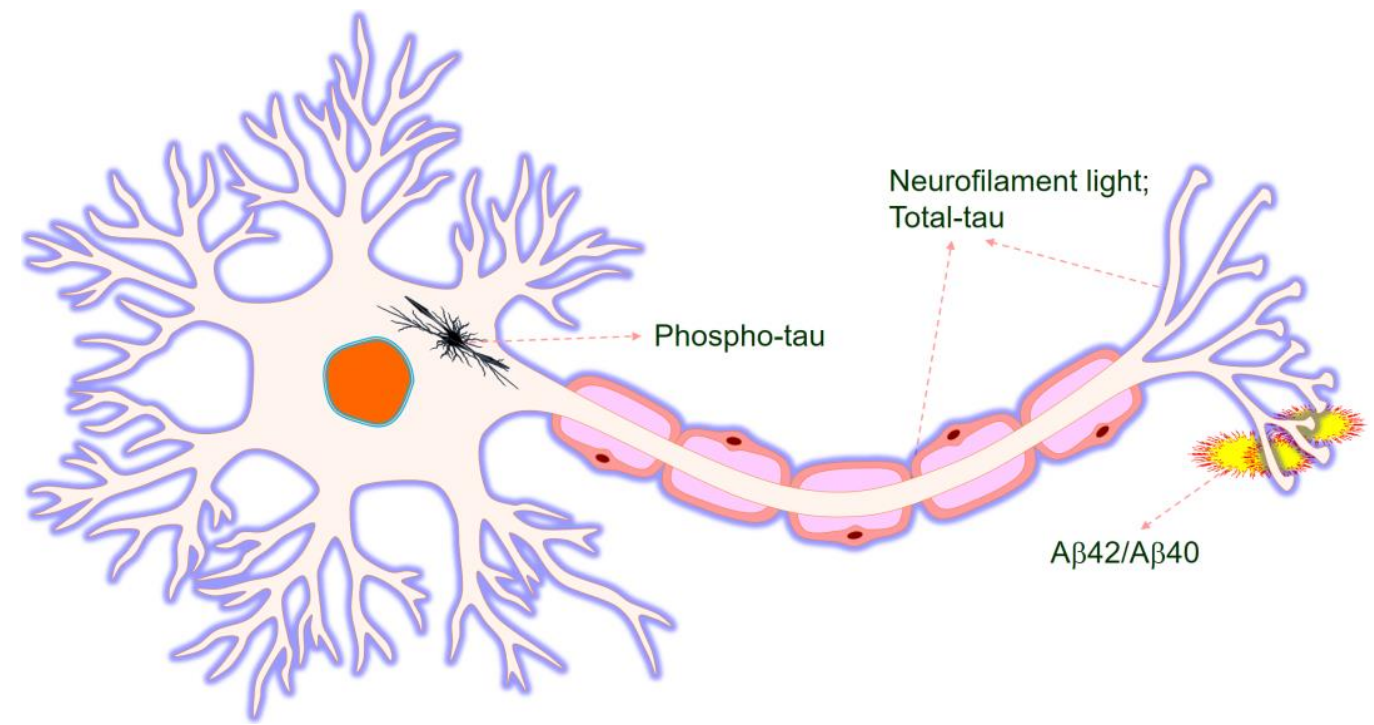

Figure 2. Neurofilament, tau and $\mathrm{A} \beta$ aggregation as indicators in the AD brain.

\subsection{Plasma Tau}

Many studies have reported that phosphorylated tau turns up in peoples' plasma decades before they show signs of dementia. The data bore the promise of a blood test for early Alzheimer's disease-one that is simpler than measuring the notoriously finicky plasma $A \beta$, and more specific than neurofilament light $[27,28,34,59,60,85-88]$. In AD patients, plasma tau concentrations are increased compared with in normal controls, which can be measured using ultrasensitive assays but not as clearly as in the CSF [89]. The relationship of plasma T-tau with disease in 458 participant patients was measured by the Simoa approach [90], which may associate with incident AD [90]. The p-tau concentration was associated with both $\mathrm{A} \beta$ and tau PET in AD patients, and it was possible to detect tau phosphorylated at amino acid 181 by an assay [91].

Plasma p-tau181 was associated with CSF p-tau181 and with tau PET, and it predicted further cognitive decline among people who were already mildly impaired. In this study, plasma p-tau181 was much more specific than plasma neurofilament light, a promising marker for neurodegeneration. People with AD had more p-tau181 in their blood than did non-diseased controls, and it correlated with their PET measures of amyloid plaques and neurofibrillary tangles [91]. In fact, plasma p-tau181 better correlated with amyloid than did the plasma $\mathrm{A} \beta 42 / \mathrm{A} \beta 40$ ratio, indicating that this particular phospho form of tau reflects ongoing $A \beta$ pathology. Recently, a study reported that p-tau181 and p-tau217 rise in the CSF of autosomal-dominant AD cases 19 and 21 years before symptom onset, respectively [92]. Plasma p-tau181 distinguished AD from all other diseases with a sensitivity and specificity of 92 and 87 percent, respectively, and an area under the curve of 0.92 . These findings show that plasma p-tau181 increases early in AD, around the timepoint of $A \beta$ positivity, and support plasma p-tau181 as a possible early marker of AD [93-95].

\subsection{Other Biomarkers in Plasma}

Given that A $\beta 42$ and tau are specific markers of AD pathogenesis, the utility of a marker of neuronal death in the diagnosis of $\mathrm{AD}$ was suggested recently [96]. Besides the core AD biomarkers CSF $A \beta 42, A \beta 40$, p-tau181 and total tau, the markers include $\alpha$-synuclein as a gauge of synaptic dysfunction; S100b, YKL-40 and glial fibrillary acidic protein (GFAP) [97] as markers of astrocyte activation; soluble TREM2 and IL-6 as markers of microglial activation and inflammation [98]; and 
neurofilament light (NfL) and neurogranin [99] as markers of axonal injury and synaptic dysfunction. Recently, specific protein biomarkers of synapse degeneration such as SNAP-25 and synaptotagmin in the CSF have been developed $[23,100,101]$. Other synaptic proteins including SNAP25, RAB3A, GAP43, AMPA receptor subunits, and a number of other proteins also show promise as CSF biomarkers of synaptic damage and loss [102-105]. The investigators vote new candidate biomarkers into this jointly evaluated set as individual research labs produce promising evidence for them. In addition, plasma clusterin, which is also called Apolipoprotein-J (APOE-J) [106,107], is mainly associated with the clearing of debris from the brain [108]. When the clusterin gene is modified or mutated, it becomes a risk factor for $\mathrm{AD}$ [106]. However, on which allele the mutation occurrs is still unclear. Clusterin exerts a protective function on the neurons, and it was suggested that it modifies the amyloid- $\beta$ aggregates by clearing them away $[106,107]$. It was also found that high clusterin levels exert protective functions in younger persons whereas they exert toxic functions in older patients. Therefore, there is an increasing burden of AD pathogenesis when the amount of CSF clusterin is increased for exerting protective functions and inhibiting apoptosis [109]. In response to the increased CSF clusterin, there is also an increased amount of plasma clusterin [110]. As a result, with the development of the severity of the disease, there is an increasing amount of plasma clusterin [110]. However, it is still not completely determined if plasma clusterin can diagnose AD at the initial level [111]. Rather, it has been suggested that the clusterin starts to increase in amount when the disease has already progressed. Thus, it can be used as a prognostic biomarker rather than a diagnostic biomarker [107].

\section{Other Potential Biomarker Sources}

Along with affecting the brain mostly, AD also affects the eyes. The retinas of the eyes contain neurons that extend to the brain and render visual signals to the brain. As a result, the proteins responsible for $\mathrm{AD}$ pathology are also present in the retina. Therefore, the eye becomes easier to access than the brain imaging. Moreover, it a non-invasive process, which means the ocular biomarkers may be useful for the diagnosis of the AD [112,113]. Several potential ocular biomarkers could be assessed for the diagnosis of the $\mathrm{AD}$, such as retinal $\mathrm{A} \beta$ accumulation, the loss of the retinal ganglion and the nerve fiber layer, retinal vascular biomarkers [114-118] and lens biomarkers [119-121].

Previous studies revealed that $A \beta$ plaques could be found in the retina in both animal models, and in humans, the retinal dysfunction was caused in AD by the accumulation of amyloid- $\beta$ proteins in the retina, which alters the normal structural functionality of the retina [122]. In almost all layers of the retina, the aggregation of $A \beta$ plaques was identified. In another study, a South American rodent showed brain $A \beta$, tau-accumulation, and cognitive impairment due to age and also retinal amyloid- $\beta$ accumulation and tau accumulation, more specifically in the nerve fibers and ganglionic cells. Moreover, in other animal studies, the A $\beta$ plaques in the case of $\mathrm{AD}$ appeared in the retina even before appearing in the brain. In some studies, it was possible to confirm AD using the $A \beta$ accumulation in the retina, though the number of the studies is very small. More extensive studies and confirmations are needed to establish retinal $\mathrm{A} \beta$ deposition as an invasive biomarker for the detection of AD [123]. In addition to the clinically most relevant biomarkers, $t$-tau, $p$-tau and A $\beta 42$ are discussed, as is how they may be used, together with other diagnostic investigations, to make a pre-dementia diagnosis of and screening test for AD early on.

\section{Conclusions and Future Perspective}

As there is no cure for the disease, the prevention of the progression of and diagnosis of $\mathrm{AD}$ at the earliest stage is very crucial. While the exact cause of the disease, risk factors and molecular understanding of the disease are still very unclear, discovering the biomarkers very specific to the disease is very important, and for diagnosing such a complex disease, it is not possible to depend on only one form of biomarker. An attractive next step in studying biomarker changes in preclinical AD would be to embark on a larger multi-center longitudinal study. The subjects would then be followed up at previously defined intervals with the repeated collection of CSF and blood and with 
neuroimaging and neuropsychological assessments. Through such prospective collection of data from a large number of individuals, where a substantial part of the study group is expected to develop clinical AD during follow-up, one would be able to map the temporal trajectories of preclinical biomarker changes with precision, thereby gaining valuable knowledge on the true course of events during the development of AD.

The representative biomarkers of $\mathrm{AD}$ are $\mathrm{A} \beta 42, \mathrm{~A} \beta 40$, total tau protein and phosphorylated tau protein, and the concentrations of these biomarkers in human plasma are directly correlated with the pathology of AD. As the disease is mainly neural related, the CSF biomarkers are the closest ones to the disease site. The major CSF biomarkers of the disease are the A $\beta$ aggregates and tau protein deposition. The $A \beta$ aggregates can also be found in other types of dementia as well, but the amount might vary, whereas tau protein deposition is very specific towards AD and is very useful in differentiating AD from the rest of the kinds of dementia. However, collecting these biomarkers is not easy; it is both time consuming and expert-dependent. Once these biomarkers are accurately correlated with the disease, they will be the easiest accessible biomarkers for the diagnosis of AD. Therefore, new biomarkers are needed to track non-A $\beta$ and non-tau pathologies. Many proteins involved in the pathophysiological progression of $\mathrm{AD}$ have shown promise as new biomarkers. Circulatory microRNAs [124], ceramides [125], neurogranin [126], neuronal pentraxin 1 [127], serum beta-secretase 1 [128], neuronal pentraxin 2 [127], APP 669-711/A $\beta$ 1-42 [129], APOE4 [130], albumin ratio [131], $\alpha$-synuclein [132], proteostasis-related biomarkers [133,134], and visinin-like protein $1[135,136]$ could aid the prediction of AD progress as well as early diagnosis (Table 2). These have direct connections to the CNS; therefore, accessing the ocular biomarkers will be helpful to easily access the CNS biomarkers.

By measuring the concentrations of AD biomarkers simultaneously, Alzheimer's patients can be discriminated from health controls with a high sensitivity, selectivity and accuracy; there are available techniques that have been developed and approved for clinical diagnostic and screening studies. Another interesting future direction would be to collect and characterize more cases of suspected reduced penetrance of familial AD mutations found across the globe. With a larger number of reduced penetrance cases, it would be possible to pursue the underlying factor causing these individuals to be spared from developing EOAD.

Although there are many biomarkers that are expected to correlate with AD pathology, those are still being investigated as to their exact relation with the AD, which is still not clear. On the other hand, suspected non-Alzheimer's pathophysiology (SNAP) has interested the field, since patients have one of several markers of neurodegeneration but test negative for brain amyloid and have not been diagnosed with a specific neurodegenerative disorder [137]. Based on current data, it appears that cognition in people with SNAP deteriorates much more slowly, if at all, than in those who have both brain amyloid and neurodegeneration [138]. Thus, there should be further confirmatory studies to establish the biomarkers and to make the diagnostic procedures more efficient. Hence, there should be more emphasis on discovering the correlations between the disease and non-invasive biomarkers and blood biomarkers, as in many of the countries, the imaging biomarkers and CSF biomarkers are still not easily accessible and are costly and, most importantly, very time consuming. In this situation, with the annually increased number of Alzheimer's patients, establishing non-invasive and circulatory biomarkers will improve the situation towards the betterment of AD. Combining biological markers and neuro-imaging improves diagnostic accuracy and reduces the number of individuals needed for a clinical trial of a new treatment. 
Table 2. Summary of the current development of body-fluid biomarkers for Alzheimer's Disease.

\begin{tabular}{|c|c|c|c|c|}
\hline Biomarker & Measuring & $\begin{array}{l}\text { Method for } \\
\text { Measurement }\end{array}$ & Monitoring & $\begin{array}{c}\text { Stage of } \\
\text { Development }\end{array}$ \\
\hline $\begin{array}{l}\mathrm{A} \beta 40 \text { amyloid and total } \mathrm{A} \beta 42 \\
\text { amyloid, free, bound, free/bound, } \\
\text { truncated, sAPP } \alpha\end{array}$ & Blood/plasma & Amyloid & $\begin{array}{l}\text { Diagnostic, } \\
\text { prognostic, } \\
\text { predictive }\end{array}$ & Clinical trials \\
\hline Fatty acid binding protein 3 & CSF & Neuronal damage & Diagnostic & Clinical trials \\
\hline Circulatory microRNAs & Blood/plasma & Cell signaling & Unknown & Preclinical \\
\hline $\begin{array}{c}\text { Multi-parameter diagnostic blood } \\
\text { test }\end{array}$ & Blood/plasma & Unknown & Diagnostic & Clinical trials \\
\hline Ceramides & Blood/plasma & Inflammation & Diagnostic & Clinical trials \\
\hline Neocortical $\beta$-amyloid burden & Blood/plasma & Amyloid & Susceptibility/risk & Clinical trials \\
\hline Blood brain barrier & $\begin{array}{l}\text { Blood/plasma, } \\
\text { imaging, CSF }\end{array}$ & Vasculature & $\begin{array}{l}\text { Diagnostic, } \\
\text { monitoring }\end{array}$ & Clinical trials \\
\hline $\begin{array}{l}\text { Blood biomarker for mtDNA } \\
\text { Damage }\end{array}$ & Blood/plasma & $\begin{array}{c}\text { Genetic } \\
\text { variation/DNA }\end{array}$ & $\begin{array}{l}\text { Diagnostic, } \\
\text { monitoring }\end{array}$ & Clinical trials \\
\hline Neurogranin & CSF & Neuronal damage & $\begin{array}{c}\text { Diagnostic, } \\
\text { susceptibility/risk }\end{array}$ & Clinical trials \\
\hline Neuronal pentraxin 1 & Blood/plasma & Neuronal damage & Diagnostic & Clinical trials \\
\hline BACE1 & Blood/plasma & Amyloid & $\begin{array}{c}\text { Diagnostic, } \\
\text { susceptibility/risk }\end{array}$ & Clinical trials \\
\hline Neuronal pentraxin 2 & CSF & Inflammation & Diagnostic & Clinical trials \\
\hline АРP 669-711/A $\beta$ 1-42 & Blood/plasma & Amyloid & Prognostic & Preclinical \\
\hline APOE4 & $\begin{array}{c}\text { Blood/plasma, } \\
\text { other bodily fluids }\end{array}$ & $\begin{array}{c}\text { Genetic } \\
\text { variation/DNA }\end{array}$ & Susceptibility/risk & $\begin{array}{l}\text { In use (FDA } \\
\text { approved) }\end{array}$ \\
\hline Neuron specific enolase & CSF & Neuronal damage & $\begin{array}{l}\text { Susceptibility/risk, } \\
\text { predictive }\end{array}$ & Clinical trials \\
\hline Albumin ratio & Blood/plasma, CSF & Amyloid & Diagnostic & Clinical trials \\
\hline $\mathrm{A} \beta 42 / \mathrm{A} \beta 40$ (Plasma) & Blood/plasma & Amyloid & $\begin{array}{l}\text { Pharmacodynamic/ } \\
\text { response, } \\
\text { susceptibility/risk, } \\
\text { safety }\end{array}$ & Clinical trials \\
\hline $\mathrm{A} \beta 1-42 / \mathrm{A} \beta 1-40$ (CSF) & CSF & Amyloid & $\begin{array}{l}\text { Diagnostic, } \\
\text { prognostic }\end{array}$ & Clinical trials \\
\hline $\mathrm{A} \beta 42$ (salivary) & Other bodily fluids & Amyloid & $\begin{array}{l}\text { Diagnostic, } \\
\text { prognostic }\end{array}$ & Clinical trials \\
\hline $\mathrm{A} \beta 42$ (blood) & Blood/plasma & Amyloid & Diagnostic & Clinical trials \\
\hline $\mathrm{A} \beta 42(\mathrm{CSF})$ & CSF & Amyloid & $\begin{array}{c}\text { Diagnostic, } \\
\text { prognostic, } \\
\text { susceptibility/risk }\end{array}$ & Clinical trials \\
\hline $\mathrm{A} \beta 1-17(\mathrm{~A} \beta 17)$ & Blood/plasma & Amyloid & Diagnostic & Preclinical \\
\hline Plasma lipoproteome & Blood/plasma & Neuronal damage & Diagnostic & Clinical trials \\
\hline$\alpha$-synuclein & CSF & Amyloid & Diagnostic & Clinical trials \\
\hline Proteostasis-related biomarkers & CSF & $\begin{array}{c}\text { Amyloid, } \\
\text { inflammation, } \\
\text { neuronal damage, } \\
\text { Tau }\end{array}$ & $\begin{array}{c}\text { Diagnostic, } \\
\text { monitoring, } \\
\text { susceptibility/risk }\end{array}$ & Clinical trials \\
\hline Tau in the biological fluids & Blood/plasma, CSF & Tau & $\begin{array}{l}\text { Diagnostic, } \\
\text { monitoring }\end{array}$ & Clinical trials \\
\hline TNF- $\alpha$ (plasma) & Blood/plasma & Inflammation & Diagnostic & Clinical trials \\
\hline Vascular cell adhesion molecule 1 & Blood/plasma & Neuronal damage & $\begin{array}{c}\text { Diagnostic, } \\
\text { monitoring, } \\
\text { prognostic }\end{array}$ & Clinical trials \\
\hline Visinin-like protein 1 & CSF & Neuronal damage & $\begin{array}{l}\text { Pharmacodynamic/ } \\
\text { response }\end{array}$ & Clinical trials \\
\hline
\end{tabular}


Author Contributions: Conceptualization, T.T.N., Q.T.H.T., T.K.O.N., T.T.D.N. and V.G.V.; collection the literature, writing-review and editing the manuscript, T.T.N., Q.T.H.T., T.T.D.N. and V.G.V.; substantive supervision and revision over the article, T.T.N. and V.G.V.; project administration, V.G.V.; funding acquisition, V.G.V. All authors have read and agreed to the published version of the manuscript.

Funding: This research was supported by a National Research Foundation of Korea (NRF) Grant, awarded by the Korean government (Ministry of Education, Science and Technology, No. NRF-2019R1G1A109740012).

Conflicts of Interest: The authors declare that there is no conflict of interest. The funders had no role in the design of the study; in the collection, analyses, or interpretation of data; in the writing of the manuscript, or in the decision to publish the results.

\section{References}

1. Freudenberg-Hua, Y.; Li, W.; Davies, P. The Role of Genetics in Advancing Precision Medicine for Alzheimer's Disease-A Narrative Review. Front. Med. (Lausanne) 2018, 5, 108. [CrossRef] [PubMed]

2. Livingston, G.; Sommerlad, A.; Orgeta, V.; Costafreda, S.G.; Huntley, J.; Ames, D.; Ballard, C.; Banerjee, S.; Burns, A.; Cohen-Mansfield, J.; et al. Dementia prevention, intervention, and care. Lancet (London, England) 2017, 390, 2673-2734. [CrossRef]

3. Prince, M.J.; Wu, F.; Guo, Y.; Robledo, L.M.G.; O'Donnell, M.; Sullivan, R.; Yusuf, S. The burden of disease in older people and implications for health policy and practice. Lancet (London, England) 2015, 385, 549-562. [CrossRef]

4. Giau, V.V.; Bagyinszky, E.; An, S.S.A.; Kim, S. Clinical genetic strategies for early onset neurodegenerative diseases. Mol. Cell. Toxicol. 2018, 14, 123-142. [CrossRef]

5. van Giau, V.; An, S.S.A.; Bagyinszky, E.; Kim, S. Gene panels and primers for next generation sequencing studies on neurodegenerative disorders. Mol. Cell. Toxicol. 2015, 11, 89-143. [CrossRef]

6. Pais, M.; Martinez, L.; Ribeiro, O.; Loureiro, J.; Fernandez, R.; Valiengo, L.; Canineu, P.; Stella, F.; Talib, L.; Radanovic, M.; et al. Early diagnosis and treatment of Alzheimer s disease: New definitions and challenges. Braz. J. Psychiatry 2020. [CrossRef]

7. Perl, D.P. Neuropathology of Alzheimer's disease. Mt. Sinai J. Med. 2010, 77, 32-42. [CrossRef]

8. Sadigh-Eteghad, S.; Sabermarouf, B.; Majdi, A.; Talebi, M.; Farhoudi, M.; Mahmoudi, J. Amyloid-Beta: A Crucial Factor in Alzheimer's Disease. Med Princ. Pract. 2015, 24, 1-10. [CrossRef]

9. Chen, G.-f.; Xu, T.-h.; Yan, Y.; Zhou, Y.-r.; Jiang, Y.; Melcher, K.; Xu, H.E. Amyloid beta: Structure, biology and structure-based therapeutic development. Acta Pharmacol. Sinica 2017, 38, 1205-1235. [CrossRef]

10. Jack, C.R.; Bennett, D.A., Jr.; Blennow, K.; Carrillo, M.C.; Dunn, B.; Haeberlein, S.B.; Holtzman, D.M.; Jagust, W.; Jessen, F.; Karlawish, J.; et al. NIA-AA Research Framework: Toward a biological definition of Alzheimer's disease. Alzheimer's Dement. J. Alzheimer's Assoc. 2018, 14, 535-562. [CrossRef]

11. Bateman, R.J.; Barthélemy, N.R.; Horie, K. Another step forward in blood-based diagnostics for Alzheimer's disease. Nat. Med. 2020, 26, 314-316. [CrossRef] [PubMed]

12. Henriksen, K.; O’Bryant, S.E.; Hampel, H.; Trojanowski, J.Q.; Montine, T.J.; Jeromin, A.; Blennow, K.; Lonneborg, A.; Wyss-Coray, T.; Soares, H.; et al. The future of blood-based biomarkers for Alzheimer's disease. Alzheimer's Dement. J. Alzheimer's Assoc. 2014, 10, 115-131. [CrossRef] [PubMed]

13. Ferreira, D.; Jelic, V.; Cavallin, L.; Oeksengaard, A.R.; Snaedal, J.; Hogh, P.; Andersen, B.B.; Naik, M.; Engedal, K.; Westman, E.; et al. Electroencephalography Is a Good Complement to Currently Established Dementia Biomarkers. Dement. Geriatr. Cogn. Disord. 2016, 42, 80-92. [CrossRef] [PubMed]

14. Wurtman, R. Biomarkers in the diagnosis and management of Alzheimer's disease. Metab. Clin. Exp. 2015, 64, S47-S50. [CrossRef] [PubMed]

15. Leuzy, A.; Heurling, K.; Ashton, N.J.; Scholl, M.; Zimmer, E.R. In vivo Detection of Alzheimer's Disease. Yale J. Biol. Med. 2018, 91, 291-300.

16. Pawlowski, M.; Meuth, S.G.; Duning, T. Cerebrospinal Fluid Biomarkers in Alzheimer's Disease-From Brain Starch to Bench and Bedside. Diagnostics 2017, 7, E42.

17. Zetterberg, H.; Rohrer, J.D.; Schott, J.M. Cerebrospinal fluid in the dementias. Handb. Clin. Neurol. 2017, 146, 85-97.

18. Zetterberg, H. Blood-based biomarkers for Alzheimer's disease-An update. J. Neurosci. Methods 2019, 319, 2-6. [CrossRef] 
19. Dubois, B.; Feldman, H.H.; Jacova, C.; Cummings, J.L.; Dekosky, S.T.; Barberger-Gateau, P.; Delacourte, A.; Frisoni, G.; Fox, N.C.; Galasko, D.; et al. Revising the definition of Alzheimer's disease: A new lexicon. Lancet Neurol. 2010, 9, 1118-1127. [CrossRef]

20. Shankar, G.M.; Li, S.; Mehta, T.H.; Garcia-Munoz, A.; Shepardson, N.E.; Smith, I.; Brett, F.M.; Farrell, M.A.; Rowan, M.J.; Lemere, C.A.; et al. Amyloid-beta protein dimers isolated directly from Alzheimer's brains impair synaptic plasticity and memory. Nat. Med. 2008, 14, 837-842. [CrossRef]

21. Lacor, P.N.; Buniel, M.C.; Furlow, P.W.; Clemente, A.S.; Velasco, P.T.; Wood, M.; Viola, K.L.; Klein, W.L. Abeta oligomer-induced aberrations in synapse composition, shape, and density provide a molecular basis for loss of connectivity in Alzheimer's disease. J. Neurosci. Off. J. Soc. Neurosci. 2007, 27, 796-807. [CrossRef] [PubMed]

22. Wang, Z.; Jackson, R.J.; Hong, W.; Taylor, W.M.; Corbett, G.T.; Moreno, A.; Liu, W.; Li, S.; Frosch, M.P.; Slutsky, I.; et al. Human Brain-Derived Abeta Oligomers Bind to Synapses and Disrupt Synaptic Activity in a Manner That Requires APP. J. Neurosci. Off. J. Soc. Neurosci. 2017, 37, 11947-11966. [CrossRef] [PubMed]

23. Calabrese, B.; Shaked, G.M.; Tabarean, I.V.; Braga, J.; Koo, E.H.; Halpain, S. Rapid, concurrent alterations in pre- and postsynaptic structure induced by naturally-secreted amyloid-beta protein. Mol. Cell. Neurosci. 2007, 35, 183-193. [CrossRef]

24. Koffie, R.M.; Hashimoto, T.; Tai, H.C.; Kay, K.R.; Serrano-Pozo, A.; Joyner, D.; Hou, S.; Kopeikina, K.J.; Frosch, M.P.; Lee, V.M.; et al. Apolipoprotein E4 effects in Alzheimer's disease are mediated by synaptotoxic oligomeric amyloid-beta. Brain A J. Neurol. 2012, 135, 2155-2168. [CrossRef]

25. Lue, L.F.; Kuo, Y.M.; Roher, A.E.; Brachova, L.; Shen, Y.; Sue, L.; Beach, T.; Kurth, J.H.; Rydel, R.E.; Rogers, J. Soluble amyloid beta peptide concentration as a predictor of synaptic change in Alzheimer's disease. Am. J. Pathol. 1999, 155, 853-862. [CrossRef]

26. Colom-Cadena, M.; Spires-Jones, T.; Zetterberg, H.; Blennow, K.; Caggiano, A.; DeKosky, S.T.; Fillit, H.; Harrison, J.E.; Schneider, L.S.; Scheltens, P.; et al. The Synaptic Health Endpoints Working, The clinical promise of biomarkers of synapse damage or loss in Alzheimer's disease. Alzheimers Res. Ther. 2020, $12,21$. [CrossRef]

27. Tapiola, T.; Alafuzoff, I.; Herukka, S.K.; Parkkinen, L.; Hartikainen, P.; Soininen, H.; Pirttila, T. Cerebrospinal fluid \{beta\}-amyloid 42 and tau proteins as biomarkers of Alzheimer-type pathologic changes in the brain. Arch. Neurol. 2009, 66, 382-389. [CrossRef]

28. Andreasen, N.; Minthon, L.; Davidsson, P.; Vanmechelen, E.; Vanderstichele, H.; Winblad, B.; Blennow, K. Evaluation of CSF-tau and CSF-Abeta42 as diagnostic markers for Alzheimer disease in clinical practice. Arch. Neurol. 2001, 58, 373-379. [CrossRef]

29. Blennow, K.; Zetterberg, H.; Minthon, L.; Lannfelt, L.; Strid, S.; Annas, P.; Basun, H.; Andreasen, N. Longitudinal stability of CSF biomarkers in Alzheimer's disease. Neurosci. Lett. 2007, 419, 18-22. [CrossRef]

30. Mattsson, N.; Portelius, E.; Rolstad, S.; Gustavsson, M.; Andreasson, U.; Stridsberg, M.; Wallin, A.; Blennow, K.; Zetterberg, H. Longitudinal cerebrospinal fluid biomarkers over four years in mild cognitive impairment. J. Alzheimer's Dis. JAD 2012, 30, 767-778. [CrossRef]

31. Zetterberg, H.; Pedersen, M.; Lind, K.; Svensson, M.; Rolstad, S.; Eckerstrom, C.; Syversen, S.; Mattsson, U.B.; Ysander, C.; Mattsson, N.; et al. Intra-individual stability of CSF biomarkers for Alzheimer's disease over two years. J. Alzheimer's Dis. JAD 2007, 12, 255-260. [CrossRef] [PubMed]

32. Andreasen, N.; Minthon, L.; Vanmechelen, E.; Vanderstichele, H.; Davidsson, P.; Winblad, B.; Blennow, K. Cerebrospinal fluid tau and Abeta42 as predictors of development of Alzheimer's disease in patients with mild cognitive impairment. Neurosci. Lett. 1999, 273, 5-8. [CrossRef]

33. Thordardottir, S.; Stahlbom, A.K.; Ferreira, D.; Almkvist, O.; Westman, E.; Zetterberg, H.; Eriksdotter, M.; Blennow, K.; Graff, C. Preclinical cerebrospinal fluid and volumetric magnetic resonance imaging biomarkers in Swedish familial Alzheimer's disease. J. Alzheimer's Dis. JAD 2015, 43, 1393-1402. [CrossRef] [PubMed]

34. Bateman, R.J.; Xiong, C.; Benzinger, T.L.; Fagan, A.M.; Goate, A.; Fox, N.C.; Marcus, D.S.; Cairns, N.J.; Xie, X.; Blazey, T.M.; et al. Clinical and biomarker changes in dominantly inherited Alzheimer's disease. N. Engl. J. Med. 2012, 367, 795-804. [CrossRef] [PubMed]

35. Vos, S.J.; Xiong, C.; Visser, P.J.; Jasielec, M.S.; Hassenstab, J.; Grant, E.A.; Cairns, N.J.; Morris, J.C.; Holtzman, D.M.; Fagan, A.M. Preclinical Alzheimer's disease and its outcome: A longitudinal cohort study. Lancet Neurol. 2013, 12, 957-965. [CrossRef] 
36. Skoog, I.; Davidsson, P.; Aevarsson, O.; Vanderstichele, H.; Vanmechelen, E.; Blennow, K. Cerebrospinal fluid beta-amyloid 42 is reduced before the onset of sporadic dementia: A population-based study in 85-year-olds. Dement. Geriatr. Cogn. Disord. 2003, 15, 169-176. [CrossRef]

37. Gustafson, D.R.; Skoog, I.; Rosengren, L.; Zetterberg, H.; Blennow, K. Cerebrospinal fluid beta-amyloid 1-42 concentration may predict cognitive decline in older women. J. Neurol. Neurosurg. Psychiatry 2007, 78, 461-464. [CrossRef]

38. Ringman, J.M.; Coppola, G.; Elashoff, D.; Rodriguez-Agudelo, Y.; Medina, L.D.; Gylys, K.; Cummings, J.L.; Cole, G.M. Cerebrospinal fluid biomarkers and proximity to diagnosis in preclinical familial Alzheimer's disease. Dement. Geriatr. Cogn. Disord. 2012, 33, 1-5. [CrossRef]

39. Dubois, B.; Feldman, H.H.; Jacova, C.; Hampel, H.; Molinuevo, J.L.; Blennow, K.; DeKosky, S.T.; Gauthier, S.; Selkoe, D.; Bateman, R.; et al. Advancing research diagnostic criteria for Alzheimer's disease: The IWG-2 criteria. Lancet Neurol. 2014, 13, 614-629. [CrossRef]

40. Buchhave, P.; Minthon, L.; Zetterberg, H.; Wallin, A.K.; Blennow, K.; Hansson, O. Cerebrospinal fluid levels of beta-amyloid 1-42, but not of tau, are fully changed already 5 to 10 years before the onset of Alzheimer dementia. Arch. Gen. Psychiatry 2012, 69, 98-106. [CrossRef]

41. Shaw, L.M.; Vanderstichele, H.; Knapik-Czajka, M.; Clark, C.M.; Aisen, P.S.; Petersen, R.C.; Blennow, K.; Soares, H.; Simon, A.; Lewczuk, P.; et al. Cerebrospinal fluid biomarker signature in Alzheimer's disease neuroimaging initiative subjects. Ann. Neurol. 2009, 65, 403-413. [CrossRef] [PubMed]

42. Visser, P.J.; Verhey, F.; Knol, D.L.; Scheltens, P.; Wahlund, L.-O.; Freund-Levi, Y.; Tsolaki, M.; Minthon, L.; Wallin, Å.K.; Hampel, H.; et al. Prevalence and prognostic value of CSF markers of Alzheimer's disease pathology in patients with subjective cognitive impairment or mild cognitive impairment in the DESCRIPA study: A prospective cohort study. Lancet Neurol. 2009, 8, 619-627. [CrossRef]

43. Giau, V.V.; Bagyinszky, E.; An, S.S.A. Potential Fluid Biomarkers for the Diagnosis of Mild Cognitive Impairment. Int. J. Mol. Sci. 2019, 20, E4149. [CrossRef] [PubMed]

44. Williams, J.H.; Wilcock, G.K.; Seeburger, J.; Dallob, A.; Laterza, O.; Potter, W.; Smith, A.D. Non-linear relationships of cerebrospinal fluid biomarker levels with cognitive function: An observational study. Alzheimers Res. Ther. 2011, 3, 5. [CrossRef]

45. Janelidze, S.; Zetterberg, H.; Mattsson, N.; Palmqvist, S.; Vanderstichele, H.; Lindberg, O.; van Westen, D.; Stomrud, E.; Minthon, L.; Blennow, K.; et al. CSF Abeta42/Abeta40 and Abeta42/Abeta38 ratios: Better diagnostic markers of Alzheimer disease. Ann. Clin. Transl. Neurol. 2016, 3, 154-165. [CrossRef]

46. Hansson, O.; Lehmann, S.; Otto, M.; Zetterberg, H.; Lewczuk, P. Advantages and disadvantages of the use of the CSF Amyloid beta (Abeta) $42 / 40$ ratio in the diagnosis of Alzheimer's Disease. Alzheimers Res. Ther. 2019, 11, 34. [CrossRef]

47. Martorana, A.; Lorenzo, F.D.; Belli, L.; Sancesario, G.; Toniolo, S.; Sallustio, F.; Sancesario, G.M.; Koch, G. Cerebrospinal Fluid Abeta42 Levels: When Physiological Become Pathological State. CNS Neurosci. Ther. 2015, 21, 921-925. [CrossRef]

48. Sjogren, M.; Gisslen, M.; Vanmechelen, E.; Blennow, K. Low cerebrospinal fluid beta-amyloid 42 in patients with acute bacterial meningitis and normalization after treatment. Neurosci. Lett. 2001, 314, 33-36. [CrossRef]

49. Portelius, E.; Mattsson, N.; Pannee, J.; Zetterberg, H.; Gisslen, M.; Vanderstichele, H.; Gkanatsiou, E.; Crespi, G.A.; Parker, M.W.; Miles, L.A.; et al. Ex vivo (18)O-labeling mass spectrometry identifies a peripheral amyloid beta clearance pathway. Mol. Neurodegener. 2017, 12, 18. [CrossRef]

50. Hampel, H.; Buerger, K.; Zinkowski, R.; Teipel, S.J.; Goernitz, A.; Andreasen, N.; Sjoegren, M.; DeBernardis, J.; Kerkman, D.; Ishiguro, K.; et al. Measurement of phosphorylated tau epitopes in the differential diagnosis of Alzheimer disease: A comparative cerebrospinal fluid study. Arch. Gen. Psychiatry 2004, 61, 95-102. [CrossRef]

51. Spiegel, J.; Pirraglia, E.; Osorio, R.S.; Glodzik, L.; Li, Y.; Tsui, W.; Louis, L.A.S.; Randall, C.; Butler, T.; Xu, J.; et al. Greater specificity for cerebrospinal fluid P-tau231 over P-tau181 in the differentiation of healthy controls from Alzheimer's disease. J. Alzheimer's Dis. JAD 2016, 49, 93-100. [CrossRef] [PubMed]

52. Fagan, A.M.; Roe, C.M.; Xiong, C.; Mintun, M.A.; Morris, J.C.; Holtzman, D.M. Cerebrospinal fluid tau/beta-amyloid(42) ratio as a prediction of cognitive decline in nondemented older adults. Arch. Neurol. 2007, 64, 343-349. [CrossRef] [PubMed] 
53. Maddalena, A.; Papassotiropoulos, A.; Muller-Tillmanns, B.; Jung, H.H.; Hegi, T.; Nitsch, R.M.; Hock, C. Biochemical diagnosis of Alzheimer disease by measuring the cerebrospinal fluid ratio of phosphorylated tau protein to beta-amyloid peptide42. Arch. Neurol. 2003, 60, 1202-1206. [CrossRef]

54. Blennow, K.; Hampel, H. CSF markers for incipient Alzheimer's disease. Lancet. Neurol. 2003, 2, 605-613. [CrossRef]

55. Blennow, K.; Dubois, B.; Fagan, A.M.; Lewczuk, P.; de Leon, M.J.; Hampel, H. Clinical utility of cerebrospinal fluid biomarkers in the diagnosis of early Alzheimer's disease. Alzheimer's Dement. J. Alzheimer's Assoc. 2015, 11, 58-69. [CrossRef]

56. Hesse, C.; Rosengren, L.; Andreasen, N.; Davidsson, P.; Vanderstichele, H.; Vanmechelen, E.; Blennow, K. Transient increase in total tau but not phospho-tau in human cerebrospinal fluid after acute stroke. Neurosci. Lett. 2001, 297, 187-190. [CrossRef]

57. Fagan, A.M.; Shaw, L.M.; Xiong, C.; Vanderstichele, H.; Mintun, M.A.; Trojanowski, J.Q.; Coart, E.; Morris, J.C.; Holtzman, D.M. Comparison of analytical platforms for cerebrospinal fluid measures of $\beta$-amyloid 1-42, total tau, and p-tau181 for identifying Alzheimer disease amyloid plaque pathology. Arch. Neurol. 2011, 68, 1137-1144. [CrossRef]

58. Diniz, B.S.; Junior, J.A.P.; Forlenza, O.V. Do CSF total tau, phosphorylated tau, and beta-amyloid 42 help to predict progression of mild cognitive impairment to Alzheimer's disease? A systematic review and meta-analysis of the literature. World J. Biol. Psychiatry Off. J. World Fed. Soc. Biol. Psychiatry 2008, 9, 172-182. [CrossRef]

59. Hansson, O.; Zetterberg, H.; Buchhave, P.; Londos, E.; Blennow, K.; Minthon, L. Association between CSF biomarkers and incipient Alzheimer's disease in patients with mild cognitive impairment: A follow-up study. Lancet Neurol. 2006, 5, 228-234. [CrossRef]

60. Wallin, A.K.; Blennow, K.; Andreasen, N.; Minthon, L. CSF biomarkers for Alzheimer's Disease: Levels of beta-amyloid, tau, phosphorylated tau relate to clinical symptoms and survival. Dement. Geriatr. Cogn. Disord. 2006, 21, 131-138. [CrossRef]

61. Mattsson, N.; Zetterberg, H.; Hansson, O.; Andreasen, N.; Parnetti, L.; Jonsson, M.; Herukka, S.K.; van der Flier, W.M.; Blankenstein, M.A.; Ewers, M.; et al. CSF biomarkers and incipient Alzheimer disease in patients with mild cognitive impairment. JAMA 2009, 302, 385-393. [CrossRef] [PubMed]

62. Shea, Y.F.; Chu, L.W.; Zhou, L.; Li, W.M.; Lin, O.Y.; Chan, M.N.; Xu, A.; Wong, R.; Ho, T.Y.; Li, K.; et al. Cerebrospinal fluid biomarkers of Alzheimer's disease in Chinese patients: A pilot study. Am. J. Alzheimer's Dis. Dement. 2013, 28, 769-775. [CrossRef] [PubMed]

63. Park, S.A.; Chae, W.S.; Kim, H.J.; Shin, H.S.; Kim, S.; Im, J.Y.; Ahn, S.I.; Min, K.D.; Yim, S.J.; Ye, B.S.; et al. Cerebrospinal Fluid Biomarkers for the Diagnosis of Alzheimer Disease in South Korea. Alzheimer Dis. Assoc. Disord. 2017, 31, 13-18. [CrossRef] [PubMed]

64. Yang, E.; Farnum, M.; Lobanov, V.; Schultz, T.; Raghavan, N.; Samtani, M.N.; Novak, G.; Narayan, V.; DiBernardo, A.I.; the Alzheimer's Disease Neuroimaging. Quantifying the Pathophysiological Timeline of Alzheimer's Disease. J. Alzheimer's Dis. 2011, 26, 745-753. [CrossRef]

65. Graff-Radford, N.R.; Crook, J.E.; Lucas, J.; Boeve, B.F.; Knopman, D.S.; Ivnik, R.J.; Smith, G.E.; Younkin, L.H.; Petersen, R.C.; Younkin, S.G. Association of low plasma Abeta42/Abeta40 ratios with increased imminent risk for mild cognitive impairment and Alzheimer disease. Arch. Neurol. 2007, 64, 354-362. [CrossRef]

66. Pesaresi, M.; Lovati, C.; Bertora, P.; Mailland, E.; Galimberti, D.; Scarpini, E.; Quadri, P.; Forloni, G.; Mariani, C. Plasma levels of beta-amyloid (1-42) in Alzheimer's disease and mild cognitive impairment. Neurobiol. Aging 2006, 27, 904-905. [CrossRef]

67. van Oijen, M.; Hofman, A.; Soares, H.D.; Koudstaal, P.J.; Breteler, M.M. Plasma Abeta(1-40) and Abeta(1-42) and the risk of dementia: A prospective case-cohort study. Lancet. Neurol. 2006, 5, 655-660. [CrossRef]

68. Zhou, L.; Chan, K.H.; Chu, L.W.; Kwan, J.S.C.; Song, Y.Q.; Chen, L.H.; Ho, P.W.L.; Cheng, O.Y.; Ho, J.W.M.; Lam, K.S.L. Plasma amyloid- $\beta$ oligomers level is a biomarker for Alzheimer's disease diagnosis. Biochem. Biophys. Res. Commun. 2012, 423, 697-702. [CrossRef]

69. Yang, Y.; Giau, V.V.; An, S.S.A.; Kim, S. Plasma Oligomeric Beta Amyloid in Alzheimer's Disease with History of Agent Orange Exposure. Dement. Neurocogn Disord. 2018, 17, 41-49. [CrossRef]

70. Bagyinszky, E.; Kang, M.J.; van Giau, V.; Shim, K.; Pyun, J.-M.; Suh, J.; An, S.S.A.; Kim, S. Novel Amyloid Precursor Protein mutation, Val669Leu ("Seoul APP”), in a Korean Early onset Alzheimer's disease patient. Neurobiol. Aging 2019, 84, 236.e1-236.e7. [CrossRef] 
71. Lambert, J.C.; Schraen-Maschke, S.; Richard, F.; Fievet, N.; Rouaud, O.; Berr, C.; Dartigues, J.F.; Tzourio, C.; Alperovitch, A.; Buee, L.; et al. Association of plasma amyloid beta with risk of dementia: The prospective Three-City Study. Neurology 2009, 73, 847-853. [CrossRef] [PubMed]

72. Wang, M.J.; Yi, S.; Han, J.-Y.; Park, S.Y.; Jang, J.-W.; Chun, I.K.; Kim, S.E.; Lee, B.S.; Kim, G.J.; Yu, J.S.; et al. Oligomeric forms of amyloid- $\beta$ protein in plasma as a potential blood-based biomarker for Alzheimer's disease. Alzheimers Res. Ther. 2017, 9, 98. [CrossRef] [PubMed]

73. An, S.S.A.; Lee, B.-S.; Yu, J.S.; Lim, K.; Kim, G.J.; Lee, R.; Kim, S.; Kang, S.; Park, Y.H.; Wang, M.J.; et al. Dynamic changes of oligomeric amyloid $\beta$ levels in plasma induced by spiked synthetic A $\beta(42)$. Alzheimers Res. Ther. 2017, 9, 86. [CrossRef] [PubMed]

74. Youn, Y.C.; Kang, S.; Suh, J.; Park, Y.H.; Kang, M.J.; Pyun, J.-M.; Choi, S.H.; Jeong, J.H.; Park, K.W.; Lee, H.-W.; et al. Blood amyloid- $\beta$ oligomerization associated with neurodegeneration of Alzheimer's disease. Alzheimers Res. Ther. 2019, 11, 40. [CrossRef] [PubMed]

75. Berman, S.E.; Clark, L.R.; Rivera-Rivera, L.A.; Norton, D.; Racine, A.M.; Rowley, H.A.; Bendlin, B.B.; Blennow, K.; Zetterberg, H.; Carlsson, C.M.; et al. Intracranial Arterial 4D Flow in Individuals with Mild Cognitive Impairment is Associated with Cognitive Performance and Amyloid Positivity. J. Alzheimer's Dis. JAD 2017, 60, 243-252. [CrossRef]

76. Bibl, M.; Esselmann, H.; Wiltfang, J. Neurochemical biomarkers in Alzheimer's disease and related disorders. Ther. Adv. Neurol. Disord. 2012, 5, 335-348. [CrossRef]

77. Ashton, N.J.; Scholl, M.; Heurling, K.; Gkanatsiou, E.; Portelius, E.; Hoglund, K.; Brinkmalm, G.; Hye, A.; Blennow, K.; Zetterberg, H. Update on biomarkers for amyloid pathology in Alzheimer's disease. Biomark. Med. 2018, 12, 799-812. [CrossRef]

78. Verberk, I.M.W.; Slot, R.E.; Verfaillie, S.C.J.; Heijst, H.; Prins, N.D.; van Berckel, B.N.M.; Scheltens, P.; Teunissen, C.E.; van der Flier, W.M. Plasma Amyloid as Prescreener for the Earliest Alzheimer Pathological Changes. Ann. Neurol. 2018, 84, 648-658. [CrossRef]

79. Janelidze, S.; Stomrud, E.; Palmqvist, S.; Zetterberg, H.; van Westen, D.; Jeromin, A.; Song, L.; Hanlon, D.; Hehir, C.A.T.; Baker, D.; et al. Plasma beta-amyloid in Alzheimer's disease and vascular disease. Sci. Rep. 2016, 6, 26801. [CrossRef]

80. Teunissen, C.E.; Chiu, M.J.; Yang, C.C.; Yang, S.Y.; Scheltens, P.; Zetterberg, H.; Blennow, K. Plasma Amyloid-beta (Abeta42) Correlates with Cerebrospinal Fluid Abeta42 in Alzheimer's Disease. J. Alzheimer's Dis. JAD 2018, 62, 1857-1863. [CrossRef]

81. Fan, L.Y.; Tzen, K.Y.; Chen, Y.F.; Chen, T.F.; Lai, Y.M.; Yen, R.F.; Huang, Y.Y.; Shiue, C.Y.; Yang, S.Y.; Chiu, M.J. The Relation Between Brain Amyloid Deposition, Cortical Atrophy, and Plasma Biomarkers in Amnesic Mild Cognitive Impairment and Alzheimer's Disease. Front. Aging Neurosci. 2018, 10, 175. [CrossRef] [PubMed]

82. Zetterberg, H.; Mörtberg, E.; Song, L.; Chang, L.; Provuncher, G.K.; Patel, P.P.; Ferrell, E.; Fournier, D.R.; Kan, C.W.; Campbell, T.G.; et al. Hypoxia Due to Cardiac Arrest Induces a Time-Dependent Increase in Serum Amyloid $\beta$ Levels in Humans. PLoS ONE 2011, 6, e28263. [CrossRef] [PubMed]

83. Nabers, A.; Perna, L.; Lange, J.; Mons, U.; Schartner, J.; Guldenhaupt, J.; Saum, K.U.; Janelidze, S.; Holleczek, B.; Rujescu, D.; et al. Amyloid blood biomarker detects Alzheimer's disease. EMBO Mol. Med. 2018, 10, e8763. [CrossRef] [PubMed]

84. Lue, L.F.; Sabbagh, M.N.; Chiu, M.J.; Jing, N.; Snyder, N.L.; Schmitz, C.; Guerra, A.; Belden, C.M.; Chen, T.F.; Yang, C.C.; et al. Plasma Levels of Abeta42 and Tau Identified Probable Alzheimer's Dementia: Findings in Two Cohorts. Front. Aging Neurosci. 2017, 9, 226. [CrossRef] [PubMed]

85. Jensen, M.; Basun, H.; Lannfelt, L. Increased cerebrospinal fluid tau in patients with Alzheimer's disease. Neurosci. Lett. 1995, 186, 189-191. [CrossRef]

86. Wallin, A.K.; Blennow, K.; Zetterberg, H.; Londos, E.; Minthon, L.; Hansson, O. CSF biomarkers predict a more malignant outcome in Alzheimer disease. Neurology 2010, 74, 1531-1537. [CrossRef]

87. Lauridsen, C.; Sando, S.B.; Moller, I.; Berge, G.; Pomary, P.K.; Grontvedt, G.R.; Salvesen, O.; Brathen, G.; White, L.R. Cerebrospinal Fluid Abeta43 Is Reduced in Early-Onset Compared to Late-Onset Alzheimer's Disease, But Has Similar Diagnostic Accuracy to Abeta42. Front. Aging Neurosci. 2017, 9, 210. [CrossRef]

88. Cicognola, C.; Brinkmalm, G.; Wahlgren, J.; Portelius, E.; Gobom, J.; Cullen, N.C.; Hansson, O.; Parnetti, L.; Constantinescu, R.; Wildsmith, K.; et al. Novel tau fragments in cerebrospinal fluid: Relation to tangle pathology and cognitive decline in Alzheimer's disease. Acta Neuropathol. 2019, 137, 279-296. [CrossRef] 
89. Zetterberg, H.; Wilson, D.; Andreasson, U.; Minthon, L.; Blennow, K.; Randall, J.; Hansson, O. Plasma tau levels in Alzheimer's disease. Alzheimers Res. Ther. 2013, 5, 9. [CrossRef]

90. Pase, M.P.; Beiser, A.S.; Himali, J.J.; Satizabal, C.L.; Aparicio, H.J.; DeCarli, C.; Chene, G.; Dufouil, C.; Seshadri, S. Assessment of Plasma Total Tau Level as a Predictive Biomarker for Dementia and Related Endophenotypes. JAMA Neurol. 2019, 76, 598-606. [CrossRef]

91. Mielke, M.M.; Hagen, C.E.; Xu, J.; Chai, X.; Vemuri, P.; Lowe, V.J.; Airey, D.C.; Knopman, D.S.; Roberts, R.O.; Machulda, M.M.; et al. Plasma phospho-tau181 increases with Alzheimer's disease clinical severity and is associated with tau- and amyloid-positron emission tomography. Alzheimer's Dement. J. Alzheimer's Assoc. 2018, 14, 989-997. [CrossRef] [PubMed]

92. Barthelemy, N.R.; Li, Y.; Joseph-Mathurin, N.; Gordon, B.A.; Hassenstab, J.; Benzinger, T.L.S.; Buckles, V.; Fagan, A.M.; Perrin, R.J.; Goate, A.M.; et al. A soluble phosphorylated tau signature links tau, amyloid and the evolution of stages of dominantly inherited Alzheimer's disease. Nat. Med. 2020, 26, 398-407. [CrossRef] [PubMed]

93. Itoh, N.; Arai, H.; Urakami, K.; Ishiguro, K.; Ohno, H.; Hampel, H.; Buerger, K.; Wiltfang, J.; Otto, M.; Kretzschmar, H.; et al. Large-scale, multicenter study of cerebrospinal fluid tau protein phosphorylated at serine 199 for the antemortem diagnosis of Alzheimer's disease. Ann. Neurol. 2001, 50, 150-156. [CrossRef] [PubMed]

94. Kohnken, R.; Buerger, K.; Zinkowski, R.; Miller, C.; Kerkman, D.; DeBernardis, J.; Shen, J.; Moller, H.J.; Davies, P.; Hampel, H. Detection of tau phosphorylated at threonine 231 in cerebrospinal fluid of Alzheimer's disease patients. Neurosci. Lett. 2000, 287, 187-190. [CrossRef]

95. Buerger, K.; Teipel, S.J.; Zinkowski, R.; Blennow, K.; Arai, H.; Engel, R.; Hofmann-Kiefer, K.; McCulloch, C.; Ptok, U.; Heun, R.; et al. CSF tau protein phosphorylated at threonine 231 correlates with cognitive decline in MCI subjects. Neurology 2002, 59, 627-629. [CrossRef] [PubMed]

96. Lee, J.M.; Blennow, K.; Andreasen, N.; Laterza, O.; Modur, V.; Olander, J.; Gao, F.; Ohlendorf, M.; Ladenson, J.H. The brain injury biomarker VLP-1 is increased in the cerebrospinal fluid of Alzheimer disease patients. Clin. Chem. 2008, 54, 1617-1623. [CrossRef]

97. Hol, E.M.; Roelofs, R.F.; Moraal, E.; Sonnemans, M.A.F.; Sluijs, J.A.; Proper, E.A.; de Graan, P.N.E.; Fischer, D.F.; van Leeuwen, F.W. Neuronal expression of GFAP in patients with Alzheimer pathology and identification of novel GFAP splice forms. Mol. Psychiatry 2003, 8, 786-796. [CrossRef]

98. Bagyinszky, E.; Giau, V.V.; Shim, K.; Suk, K.; An, S.S.A.; Kim, S. Role of inflammatory molecules in the Alzheimer's disease progression and diagnosis. J. Neurol. Sci. 2017, 376, 242-254. [CrossRef]

99. Jin, M.; Cao, L.; Dai, Y.-P. Role of Neurofilament Light Chain as a Potential Biomarker for Alzheimer's Disease: A Correlative Meta-Analysis. Front. Aging Neurosci. 2019, 11, 254. [CrossRef]

100. Davidsson, P.; Jahn, R.; Bergquist, J.; Ekman, R.; Blennow, K. Synaptotagmin, a synaptic vesicle protein, is present in human cerebrospinal fluid: A new biochemical marker for synaptic pathology in Alzheimer disease? Mol. Chem. Neuropathol. 1996, 27, 195-210. [CrossRef]

101. Thorsell, A.; Bjerke, M.; Gobom, J.; Brunhage, E.; Vanmechelen, E.; Andreasen, N.; Hansson, O.; Minthon, L.; Zetterberg, H.; Blennow, K. Neurogranin in cerebrospinal fluid as a marker of synaptic degeneration in Alzheimer's disease. Brain Res. 2010, 1362, 13-22. [CrossRef] [PubMed]

102. Bereczki, E.; Branca, R.M.; Francis, P.T.; Pereira, J.B.; Baek, J.H.; Hortobagyi, T.; Winblad, B.; Ballard, C.; Lehtio, J.; Aarsland, D. Synaptic markers of cognitive decline in neurodegenerative diseases: A proteomic approach. Brain A J. Neurol. 2018, 141, 582-595. [CrossRef] [PubMed]

103. Bereczki, E.; Francis, P.T.; Howlett, D.; Pereira, J.B.; Hoglund, K.; Bogstedt, A.; Cedazo-Minguez, A.; Baek, J.H.; Hortobagyi, T.; Attems, J.; et al. Synaptic proteins predict cognitive decline in Alzheimer's disease and Lewy body dementia. Alzheimer's Dement. J. Alzheimer's Assoc. 2016, 12, 1149-1158. [CrossRef] [PubMed]

104. Sandelius, A.; Portelius, E.; Kallen, A.; Zetterberg, H.; Rot, U.; Olsson, B.; Toledo, J.B.; Shaw, L.M.; Lee, V.M.Y.; Irwin, D.J.; et al. Elevated CSF GAP-43 is Alzheimer's disease specific and associated with tau and amyloid pathology. Alzheimer's Dement. J. Alzheimer's Assoc. 2019, 15, 55-64. [CrossRef] [PubMed]

105. Brinkmalm, A.; Brinkmalm, G.; Honer, W.G.; Frolich, L.; Hausner, L.; Minthon, L.; Hansson, O.; Wallin, A.; Zetterberg, H.; Blennow, K.; et al. SNAP-25 is a promising novel cerebrospinal fluid biomarker for synapse degeneration in Alzheimer's disease. Mol. Neurodegener. 2014, 9, 53. [CrossRef]

106. van Giau, V.; An, S.S.A. Optimization of specific multiplex DNA primers to detect variable CLU genomic lesions in patients with Alzheimer's disease. BioChip J. 2015, 9, 278-284. [CrossRef] 
107. Foster, E.M.; Dangla-Valls, A.; Lovestone, S.; Ribe, E.M.; Buckley, N.J. Clusterin in Alzheimer's Disease: Mechanisms, Genetics, and Lessons From Other Pathologies. Front. Neurosci. 2019, 13, 164. [CrossRef]

108. Elliott, D.A.; Weickert, C.S.; Garner, B. Apolipoproteins in the brain: Implications for neurological and psychiatric disorders. Clin. Lipidol. 2010, 51, 555-573. [CrossRef]

109. Wang, J.; Zhang, X.; Zhu, B.; Fu, P.; On the behalf of Alzheimer's Disease Neuroimaging. Association of Clusterin Levels in Cerebrospinal Fluid with Synaptic Degeneration Across the Alzheimer's Disease Continuum. Neuropsychiatr. Dis. Treat. 2020, 16, 183-190. [CrossRef]

110. Hsu, J.-L.; Lee, W.-J.; Liao, Y.-C.; Wang, S.-J.; Fuh, J.-L. The clinical significance of plasma clusterin and A $\beta$ in the longitudinal follow-up of patients with Alzheimer's disease. Alzheimers Res. Ther. 2017, 9, 91. [CrossRef]

111. Silajdzic, E.; Minthon, L.; Bjorkqvist, M.; Hansson, O. No diagnostic value of plasma clusterin in Alzheimer's disease. PLoS ONE 2012, 7, e50237. [CrossRef] [PubMed]

112. Frost, S.; Martins, R.N.; Kanagasingam, Y. Ocular biomarkers for early detection of Alzheimer's disease. J. Alzheimer's Dis. JAD 2010, 22, 1-16. [CrossRef] [PubMed]

113. Frost, S.; Kanagasingam, Y.; Sohrabi, H.; Vignarajan, J.; Bourgeat, P.; Salvado, O.; Villemagne, V.; Rowe, C.C.; Macaulay, S.L.; Szoeke, C.; et al. Retinal vascular biomarkers for early detection and monitoring of Alzheimer's disease. Transl. Psychiatry 2013, 3, e233. [CrossRef] [PubMed]

114. Koychev, I.; Galna, B.; Zetterberg, H.; Lawson, J.; Zamboni, G.; Ridha, B.H.; Rowe, J.B.; Thomas, A.; Howard, R.; Malhotra, P.; et al. Abeta42/Abeta40 and Abeta42/Abeta38 Ratios Are Associated with Measures of Gait Variability and Activities of Daily Living in Mild Alzheimer's Disease: A Pilot Study. J. Alzheimer's Dis. JAD 2018, 65, 1377-1383. [CrossRef] [PubMed]

115. Koronyo, Y.; Salumbides, B.C.; Black, K.L.; Koronyo-Hamaoui, M. Alzheimer's disease in the retina: Imaging retinal abeta plaques for early diagnosis and therapy assessment. Neuro-Degener. Dis. 2012, 10, 285-293. [CrossRef] [PubMed]

116. Morgia, C.L.; Ross-Cisneros, F.N.; Koronyo, Y.; Hannibal, J.; Gallassi, R.; Cantalupo, G.; Sambati, L.; Pan, B.X.; Tozer, K.R.; Barboni, P.; et al. Melanopsin retinal ganglion cell loss in Alzheimer disease. Ann. Neurol. 2016, 79, 90-109. [CrossRef]

117. Koronyo-Hamaoui, M.; Koronyo, Y.; Ljubimov, A.V.; Miller, C.A.; Ko, M.K.; Black, K.L.; Schwartz, M.; Farkas, D.L. Identification of amyloid plaques in retinas from Alzheimer's patients and noninvasive in vivo optical imaging of retinal plaques in a mouse model. NeuroImage 2011, 54 (Suppl. 1), S204-S217. [CrossRef]

118. Dutescu, R.M.; Li, Q.X.; Crowston, J.; Masters, C.L.; Baird, P.N.; Culvenor, J.G. Amyloid precursor protein processing and retinal pathology in mouse models of Alzheimer's disease. Graefe's Arch. Clin. Exp. Ophthalmol. Albrecht von Graefes Arch. fur Klin. und Exp. Ophthalmol. 2009, 247, 1213-1221. [CrossRef]

119. Frederikse, P.H.; Garland, D.; Zigler, J.S.; Piatigorsky, J., Jr. Oxidative stress increases production of beta-amyloid precursor protein and beta-amyloid (Abeta) in mammalian lenses, and Abeta has toxic effects on lens epithelial cells. J. Biol. Chem. 1996, 271, 10169-10174. [CrossRef]

120. Goldstein, L.E.; Muffat, J.A.; Cherny, R.A.; Moir, R.D.; Ericsson, M.H.; Huang, X.; Mavros, C.; Coccia, J.A.; Faget, K.Y.; Fitch, K.A.; et al. Cytosolic beta-amyloid deposition and supranuclear cataracts in lenses from people with Alzheimer's disease. Lancet (London, England) 2003, 361, 1258-1265. [CrossRef]

121. Moncaster, J.A.; Pineda, R.; Moir, R.D.; Lu, S.; Burton, M.A.; Ghosh, J.G.; Ericsson, M.; Soscia, S.J.; Mocofanescu, A.; Folkerth, R.D.; et al. Alzheimer's disease amyloid-beta links lens and brain pathology in Down syndrome. PLoS ONE 2010, 5, e10659. [CrossRef] [PubMed]

122. Gupta, V.K.; Chitranshi, N.; Gupta, V.B.; Golzan, M.; Dheer, Y.; Wall, R.V.; Georgevsky, D.; King, A.E.; Vickers, J.C.; Chung, R.; et al. Amyloid beta accumulation and inner retinal degenerative changes in Alzheimer's disease transgenic mouse. Neurosci. Lett. 2016, 623, 52-56. [CrossRef] [PubMed]

123. van Wijngaarden, P.; Hadoux, X.; Alwan, M.; Keel, S.; Dirani, M. Emerging ocular biomarkers of Alzheimer disease. Clin. Exp. Ophthalmol. 2017, 45, 54-61. [CrossRef] [PubMed]

124. van Giau, V.; An, S.S. Emergence of exosomal miRNAs as a diagnostic biomarker for Alzheimer's disease. J. Neurol. Sci. 2016, 360, 141-152. [CrossRef]

125. Lee, J.Y.; Jin, H.K.; Bae, J.-S. Sphingolipids in neuroinflammation: A potential target for diagnosis and therapy. BMB Rep. 2020, 53, 28-34. [CrossRef]

126. Milà-Alomà, M.; Suárez-Calvet, M.; Molinuevo, J.L. Latest advances in cerebrospinal fluid and blood biomarkers of Alzheimer's disease. Ther. Adv. Neurol. Disord. 2019. [CrossRef] 
127. Ma, Q.L.; Teng, E.; Zuo, X.; Jones, M.; Teter, B.; Zhao, E.Y.; Zhu, C.; Bilousova, T.; Gylys, K.H.; Apostolova, L.G.; et al. Neuronal pentraxin 1: A synaptic-derived plasma biomarker in Alzheimer's disease. Neurobiol. Dis. 2018, 114, 120-128. [CrossRef]

128. Cervellati, C.; Trentini, A.; Rosta, V.; Passaro, A.; Bosi, C.; Sanz, J.M.; Bonazzi, S.; Pacifico, S.; Seripa, D.; Valacchi, G.; et al. Serum beta-secretase 1 (BACE1) activity as candidate biomarker for late-onset Alzheimer's disease. GeroScience 2020, 42, 159-167. [CrossRef]

129. Crunkhorn, S. Identification of blood-based biomarkers. Nat. Rev. Drug Discov. 2018, 17, 166. [CrossRef]

130. Giau, V.V.; Bagyinszky, E.; An, S.S.; Kim, S.Y. Role of apolipoprotein E in neurodegenerative diseases. Neuropsychiatr. Dis. Treat. 2015, 11, 1723-1737. [CrossRef]

131. Menendez-Gonzalez, M.; Gasparovic, C. Albumin Exchange in Alzheimer's Disease: Might CSF Be an Alternative Route to Plasma? Front. Neurol. 2019, 10, 1036. [CrossRef] [PubMed]

132. Twohig, D.; Nielsen, H.M. $\alpha$-synuclein in the pathophysiology of Alzheimer's disease. Mol. Neurodegener. 2019, 14, 23. [CrossRef] [PubMed]

133. Cheng, J.; North, B.J.; Zhang, T.; Dai, X.; Tao, K.; Guo, J.; Wei, W. The emerging roles of protein homeostasis-governing pathways in Alzheimer's disease. Aging Cell 2018, 17, e12801. [CrossRef] [PubMed]

134. Labbadia, J.; Morimoto, R.I. The biology of proteostasis in aging and disease. Annu. Rev. Biochem. 2015, 84, 435-464. [CrossRef]

135. Tarawneh, R.; D’Angelo, G.; Macy, E.; Xiong, C.; Carter, D.; Cairns, N.J.; Fagan, A.M.; Head, D.; Mintun, M.A.; Ladenson, J.H.; et al. Visinin-like protein-1: Diagnostic and prognostic biomarker in Alzheimer disease. Ann. Neurol. 2011, 70, 274-285. [CrossRef]

136. Schindler, S.E.; Li, Y.; Todd, K.W.; Herries, E.M.; Henson, R.L.; Gray, J.D.; Wang, G.; Graham, D.L.; Shaw, L.M.; Trojanowski, J.Q.; et al. Emerging cerebrospinal fluid biomarkers in autosomal dominant Alzheimer's disease. Alzheimer's Dement. 2019, 15, 655-665. [CrossRef]

137. Jack, C.R.; Knopman, D.S., Jr.; Weigand, S.D.; Wiste, H.J.; Vemuri, P.; Lowe, V.; Kantarci, K.; Gunter, J.L.; Senjem, M.L.; Ivnik, R.J.; et al. An operational approach to National Institute on Aging-Alzheimer's Association criteria for preclinical Alzheimer disease. Ann. Neurol. 2012, 71, 765-775. [CrossRef]

138. Dani, M.; Brooks, D.J.; Edison, P. Suspected non-Alzheimer's pathology - Is it non-Alzheimer's or non-amyloid? Ageing Res. Rev. 2017, 36, 20-31. [CrossRef]

(C) 2020 by the authors. Licensee MDPI, Basel, Switzerland. This article is an open access article distributed under the terms and conditions of the Creative Commons Attribution (CC BY) license (http://creativecommons.org/licenses/by/4.0/). 